\title{
Plant growth regulating activity of coumarin derivatives
}

\begin{abstract}
Aims: coumarins are herbicides occur naturally in all parts of plants and are widely used as medicine. The present work reports the plant growth regulating activity of coumarin derivatives which may or may not found naturally.
\end{abstract}

Method: A series of coumarin was prepared by reacting phenols with malic acid and diethyl acetoacetate. Compounds were tested for seed germination inhibitory activity using wheat and sorghum seeds and effects on seedling growth for 5-days.

Results: Some of the compounds had potential seed germination inhibition activity and exhibited reductions in shoot growth and root growth of developing young seedlings compared with that of untreated or control. All compounds exhibited 60-90\% inhibitions in seed germination of shoot and root growth at lower and higher concentrations.

Conclusion: coumarins used to delay the germination of seeds simply by lowering the metabolic process during the imbibitions but early growth of seed show somewhat acceleration

Keywords: Plant growth regulation, coumarins, malic acid, ethyl acetoacetate, seed germination, sorghum, wheat
Volume 2 Issue 2 - 2018

\section{Fauzia Anjum Chattha, Munawar Ali Munawar, Samina Kousar}

Department of Chemistry, University of the Punjab, Pakistan

Correspondence: Munawar Ali Munawar, Institute of Chemistry, University of the Punjab, Lahore-54590, Pakistan, Tel 092-3004392363, Fax 092-55-920I223

Email mamunawar@chem.pu.edu.pk

Received: May 4, 2017 | Published: April 06, 2018

\section{Graphical abstract}

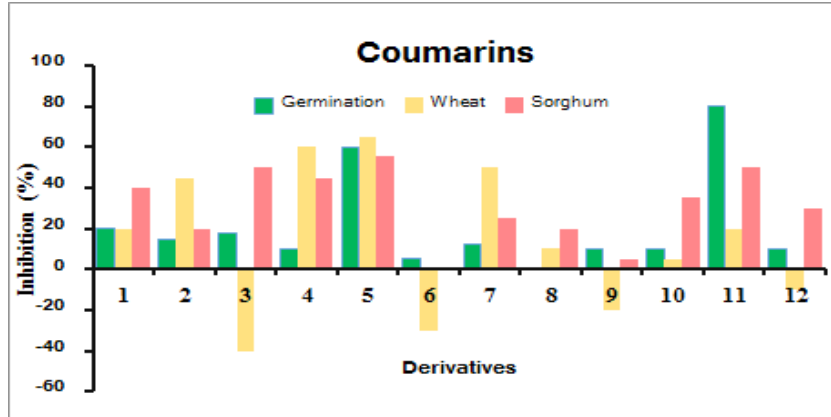

\section{Introduction}

Coumarins naturally occurs on the surface of leaves, flowers, seeds and fruits of leguminosae, Rutaceae are of great medicinal importance. Coumarins are found in almost in every plant family. The main role of coumarins is to act as growth inhibitors (antiauxins) as well as defense compounds. In some plants families like Leguminoseae (bean family), Rutaceae (citrus family) and Umbelliferae (Apiaceae) (parsley-fennel family) Coumarins inhibit seed germination at high concentration ${ }^{1}$ and inhibition occurs during the early phase of seed imbibitions by inhibition of water intake, electrolyte retention capacity and oxygen consumption and finally includes inactivation of vital enzymes. ${ }^{2}$ Coumarins are produced and used in larger quantities in most of plants varieties. ${ }^{3,4}$ Williams et $a l^{4}$ have described that hydration and dehydration of radish (Raphanus sativus L.) seeds in the presence of coumarin delay the germination and reduce the seedling growth. Coumarin derivative, 4-methylumbelliferone inhibits seed germination by mainly reducing primary root growth. ${ }^{5}$ Chemical investigation of naturally occurring plant growth inhibitors from Rutaceous plants in Thailand led us to identify five 7-methoxycoumarins and one 5,7-dimethoxycoumarin from Murraya paniculata, and six furanocoumarins from Citrus aurantifolia. Of these compounds, murranganon senecioate is a new natural compound found in M. paniculata. Minumicrolin (6) was found to be highly active against the $2^{\text {nd }}$ leaf sheath elongation of rice seedlings. ${ }^{6}$ The plant growth regulators identified in plants most often regulate cell elongation, cell division and differentiation of plant cells and they have multiple effects in plants. . Coumarins play an appreciable role in plant biochemistry and physiology especially acts as an antioxidants, enzyme inhibitors, and precursors of toxic substances. Particularly, these compounds are proved to be involved in the actions of plant growth hormones and growth regulators, control the respiration, photosynthesis, along with defense against infection. ${ }^{7}$ A series of coumarin were prepared and tested for their effects on seed germination and seedling growth using wheat and sorghum seeds. Some of these compounds owned to have potential seed germination inhibition activity and have shown reductions in shoot growth and root growth of developing young seedlings $(45-95 \%$ reduction at 1 ppm) compared to untreated or controlled seeds

\section{Synthesis of coumarins}

The synthesis of coumarin was carried out in a household microwave oven (Dawlance DW-162, $1000 \mathrm{~W}, 2450 \mathrm{MHz}$ ) with high yield and less side product. ${ }^{8}$

\section{Seed germination inhibition studies}

Effects of synthesized compounds on the seed germination inhibitory activity were determined using wheat and sorghum seeds of high viability. ${ }^{9}$ Wheat and sorghum seeds were placed per Petri dish soaked with $8 \mathrm{ml}$ distilled water and concentration of test compounds 
on double layered filter paper. Petri dishes were placed at $25^{\circ} \mathrm{C}$ in an incubator. The number of seeds germinated after 1 day, 2 day and 3 day was monitored. Protrusion of radical was an index of completion of seed germination. Each experiment was performed in triplicate. Indole butyric acid (IBA) and abscisic acids (ABA) and control were used as standards. The number of secondary roots in wheat seedlings, root length and shoot lengths were measured on $3^{\text {rd }}$ day and $5^{\text {th }}$ day respectively.

\section{Results and discussion}

A series of coumarins (Figure 1) were prepared by heating a variety of phenols with malic acid /ethyl acetoacetate in the presence of catalytic amount of concentrated sulfuric acid under microwave irradiations for 20-60 seconds (Table 1). The identities of these coumarins were confirmed by their IR, ${ }^{1} \mathrm{HNMR},{ }^{13} \mathrm{CNMR}$, mass spectral data, CHNS analysis and comparing their melting point with reported values.

\section{Effects on seed germination}

Abscisic acid (ABA) is a plant growth inhibitor and indole butyric acid (IBA) is plant growth activator. At 100 ppm both ABA and IBA suppress the germination of wheat and sorghum seeds, although this effect is more pronounced in ABA (1) rather than IBA (2). At 10 ppm germination percentage is $60-90 \%$ while at $1 \mathrm{ppm}$ germination in IBA is $>90 \%$ in both wheat and sorghum but ABA showed 75 -
$90 \%$ germination. Wheat and sorghum seeds were tested for the germination inhibitory activity of test compounds. Data shows that at $100 \mathrm{ppm}, \mathbf{4}$ and $\mathbf{1 1}$ almost completely inhibited germination. All of these compounds showed $70-95 \%$ germination at $10 \mathrm{ppm}$ and $1 \mathrm{ppm}$ (Figures 2). When data was compared with control, it was seen that all compounds showed percentage germination equal to that of control except compounds $\mathbf{4}$ and $\mathbf{1 1}$ that showed inhibited germination, at 100 ppm and percentage germination was $<50 \%$ but all other compounds had no effect on germination. Letham ${ }^{10}$ substantiated that coumarins inhibit seed germination dependent on concentration and it's more evident above $200 \mu \mathrm{M}$. Inhibition occurs during the early phase of seed imbibitions and it inhibits water imbibitions, electrolyte retention capacity and oxygen consumption and later effects include inactivation of vital enzymes. ${ }^{11}$

\section{Effects on root length}

In case of wheat no root length was observed at $100 \mathrm{ppm}$ by ABA (1) but at $10 \mathrm{ppm}$ somewhat reduced root length was observed while at $1 \mathrm{ppm}$ root length observed compared to untreated water or control. In sorghum seeds, at $100 \mathrm{ppm}$ ABA (1) showed extremely reduced root growth and at $10 \mathrm{ppm}$ reduced root length was observed while at $1 \mathrm{ppm}$ no significant difference was observed with root length of untreated control (Table 2) (Figure 3). IBA (1) at $100 \mathrm{ppm}$ exhibited reduced root growth while at $10 \mathrm{ppm}$ normal root length was observed but at 1 ppm root length was increased (Table 2) (Figure 3).

Table I Optimization of reaction conditions and physical properties of coumarins

\begin{tabular}{|c|c|c|c|c|c|c|}
\hline No. & Compound & Phenol & Reagent & Yield (\%) & M. p. (oC) & M. p. lit. (oC) \\
\hline 1 & coumarin & phenol & Malic acid & 80 & $69-70$ & 71 \\
\hline \multirow[t]{2}{*}{2} & 7-Methoxy & m-methoxy & malic acid & 71 & 116 & $117-8$ \\
\hline & coumarin & phenol & & & & \\
\hline \multirow[t]{2}{*}{3} & 6-Hydroxy & hydroquinone & malic acid & 72 & $248-250$ & 250 \\
\hline & coumarin & & & & & \\
\hline \multirow[t]{2}{*}{4} & 7-Hydroxy & resorcinol & malic acid & 64 & 228 & $228-230$ \\
\hline & coumarin & & & & & \\
\hline \multirow[t]{2}{*}{5} & 7-Methyl & m-cresol & malic acid & 96 & 128 & $128-130$ \\
\hline & coumarin & & & & & \\
\hline \multirow[t]{2}{*}{6} & 6-Methyl & p-cresol & malic acid & 60 & 74 & $73-78$ \\
\hline & coumarin & & & & & \\
\hline \multirow[t]{2}{*}{7} & 4-Methyl & phenol & diethyl acetoacetate & 50 & 83 & $83-85$ \\
\hline & coumarin & & & & & \\
\hline \multirow[t]{2}{*}{8} & 4,6-Dimethyl & p-cresol & diethyl acetoacetate & 54 & $151-152$ & 150 \\
\hline & coumarin & & & & & \\
\hline \multirow[t]{2}{*}{9} & 7-methoxy-4-methyl & m-methoxy & diethyl acetoacetate & 67 & $156-157$ & $156-158$ \\
\hline & coumarin & phenol & & & & \\
\hline 10 & 6-Hydroxy-4-methyl coumarin & hydroquinone & diethyl acetoacetate & 56 & 244 & 245 \\
\hline 11 & 7-hydroxy-4-methylcoumarin & resorcinol & diethyl acetoacetate & 90 & 185 & $184-186$ \\
\hline 12 & 5-hydroxy-4,7-dimethylcoumarin & orcinol & diethyl acetoacetate & 88 & $246-247$ & 248 \\
\hline
\end{tabular}


Table 2 Effects of various concentrations of coumarins (I-I2) on the root and shoot lengths $(\mathrm{mm})$ on the $5^{\text {th }}$ day of wheat seed germination. Numbers in ( ) indicate the number of seeds showed protrusion. NA stands for experiment not done

\begin{tabular}{|c|c|c|c|c|c|c|}
\hline \multirow{3}{*}{ Compound } & \multicolumn{6}{|c|}{ Concentration of compounds } \\
\hline & \multicolumn{2}{|l|}{100 ppm } & \multicolumn{2}{|l|}{10 ppm } & \multicolumn{2}{|l|}{ I ppm } \\
\hline & Root & Shoot & Root & Shoot & Root & Shoot \\
\hline ABA & 0 & 0 & $9.1 \pm 0.2$ & $10.5 \pm 0.7$ & $14.5 \pm 1.8$ & $12.8 \pm 1.3$ \\
\hline IBA & $16.3 \pm 1.5$ & $6.5 \pm 0.7$ & $39.7 \pm 1.3$ & $24 \pm 1.2$ & $56 \pm 2.8$ & $29 \pm 1.6$ \\
\hline 1 & $28 \pm 0.3(n=10)$ & $23 \pm 0.4(n=10)$ & $45 \pm 1.0(n=10)$ & $40 \pm 0.7(n=10)$ & $30 \pm 0.9(n=10)$ & $21 \pm 0.5(n=10)$ \\
\hline 2 & $10 \pm 0.1(n=10)$ & $15 \pm 0.2(n=10)$ & $26 \pm 0.2(n=10)$ & $30 \pm 9.2(n=10)$ & $52 \pm 0.7(n=10)$ & $33 \pm 0.2(n=10)$ \\
\hline 3 & $49 \pm 1.6(n=10)$ & $52 \pm 1.3(n=10)$ & $98 \pm 0.9(n=9)$ & $66 \pm 0.7(n=9)$ & $85 \pm 1.5(n-=8)$ & $56 \pm 1.4(n=9)$ \\
\hline 4 & $1.0 \pm 0.0(n=3)$ & $1.0 \pm 0.0(n=3)$ & $21 \pm 0.4(n=10)$ & $17 \pm 0.5(n=10)$ & $36 \pm 0.5(n=9)$ & $21 \pm 0.5(n=9)$ \\
\hline 5 & $2.0 \pm 0.1(n=9)$ & $2.7 \pm 0.1 \quad(n=9)$ & $17 \pm 0.4(n=9)$ & $25 \pm 0.2(n=9)$ & $55 \pm 2.2(n=10)$ & $60 \pm 1.4(n=10)$ \\
\hline 6 & $53 \pm 1.3(n=9)$ & $24 \pm 1.6(n=10)$ & $88 \pm 2.4(n=9)$ & $64 \pm 0.6(n=9)$ & $87 \pm 3.3(n=10)$ & $59 \pm 1.6(n=10)$ \\
\hline 7 & $12 \pm 0.1 \quad(n=10)$ & $9 \pm 0.2(n=10)$ & $3 \mid \pm 1.1 \quad(n=10)$ & $24 \pm 1.7(n=10)$ & $49 \pm 0.9(n=10)$ & $34 \pm 0.4(n=10)$ \\
\hline 8 & $54 \pm 1.5(n=10)$ & $34 \pm 1.0(n=10)$ & $60 \pm 3.2(n=10)$ & $33 \pm 0.6(n=10)$ & $84 \pm 1.7(n=10)$ & $52 \pm 1.7(n=10)$ \\
\hline 9 & $37 \pm 1.5(n=9)$ & $36 \pm 1.6(n=10)$ & $82 \pm 1.6(n=10)$ & $63 \pm 1.2(n=10)$ & $63 \pm 3.0(n=10)$ & $53 \pm 1.7(n=10)$ \\
\hline 10 & $12 \pm 0.2(n=10)$ & $17 \pm 0.3(n=10)$ & $49 \pm 1.4(n=9)$ & $53 \pm 1.0(n=9)$ & $45 \pm 1.6(n=10)$ & $51 \pm 0.8(n=10)$ \\
\hline 11 & NA & NA & $44 \pm 0.6(n=10)$ & $33 \pm 0.3(n=10)$ & $52 \pm 0.7(n=10)$ & $32 \pm 0.3(n=10)$ \\
\hline 12 & $70 \pm 2.0(n=9)$ & $58 \pm 1.5(n=9)$ & $77 \pm 2.2(n=10)$ & $56 \pm 1.1(n=10)$ & $96 \pm 1.2(n=10)$ & $64 \pm 0.2(n=10)$ \\
\hline Control & Root length & $68 \pm 0.5(n=10)$ & & Shoot length & $44 \pm 0.9(n=10)$ & \\
\hline
\end{tabular}

\section{Effects on root length}

Changes in root length $(\mathrm{mm})$ were monitored on $5^{\text {th }}$ day of wheat seed germination. Root growth was inhibited by $70-90 \%$. At all concentrations 2, 7, 8 and $\mathbf{1 1}$ had the least root growth activity at $100 \mathrm{ppm}$. At $10 \mathrm{ppm}, 70-90 \%$ root length was inhibited by $\mathbf{2}, \mathbf{5}$. 3, 6, 8 demonstrated no effect on root length and was close to the control value. Rest of all the compounds at this concentration showed inhibition of root growth between $30-60 \%$. At 1 ppm, 5 showed $>80 \%$ reduction in root growth (Table 2) (Figure 3). The change in root length $(\mathrm{mm})$ in sorghum seedlings were monitored on $5^{\text {th }}$ day of germination, similar profiles was noticed. 2 were the most effective inhibitors of root growth at $100 \mathrm{ppm}$ compared with that of control. However, root growth was induced by $20-40 \%$ at this concentration by 3, 6 and 7. Similar profiles were observed at $10 \mathrm{ppm}, \mathbf{4}$ inhibited root growths in the range of $60-90 \%$ and $\mathbf{3}, \mathbf{6 , 7}, \mathbf{8 , 1 2}$ had stimulatory effect on root growth compared with that of control (Table 3). When growth results of sorghum seeds were compared with that of control, it was seen that 3, 6,9 showed root growth equal to that of control except that 11 showed accelerated root growth at $100 \mathrm{ppm}$. While at 10 ppm, 2, 4, 5 and 7 inhibited root growth but 3, 6, 8 and 9 showed more growth of seedlings than the control. Coumarin 1, 9, 10 and $\mathbf{1 1}$ did not have any comparable effect on root growth. At 1 ppm, 3, 6, 9 and $\mathbf{1 0}$ were active than that of control. All other compounds showed moderate growth (Table 3 ). In sorghum, 1, 3, 4, 5, 10 and $\mathbf{1 1}$ are strong growth inhibitors whilst others show no effect on growth. 2, 6, 8 and 9 are probably have shoot inhibiting effect exerting little or no root inhibition (Figure 4). In the present work, coumarins proved to be good inhibitors of both root and shoot in wheat. The inhibition effect was more pronounced in sorghum. Accordingly, coumarins inhibited seed germination at $100 \mathrm{ppm}$ and its effects became less prominent at low concentrations.

Table 3 Effects of various concentrations of coumarins (I-I2) on the root and shoot lengths (mm) on the 5th day of sorghum seed germination. Results are expressed in terms of mean \pm sem. Numbers in ( ) indicate the number of seeds showed protrusion. For NA stands for experiment not done

\begin{tabular}{|c|c|c|c|c|c|c|}
\hline \multirow{3}{*}{ Compound } & \multicolumn{6}{|c|}{ Concentration of compounds } \\
\hline & \multicolumn{2}{|l|}{100 ppm } & \multicolumn{2}{|l|}{10 ppm } & \multicolumn{2}{|l|}{1 ppm } \\
\hline & Root & Shoot & Root & Shoot & Root & Shoot \\
\hline $\mathrm{ABA}$ & $1.0 \pm 0.3$ & $1.0 \pm 0.4$ & $10 \pm 0.4$ & $2.2 \pm 0.3$ & $68.7 \pm 0.7$ & $48.5 \pm 0.3$ \\
\hline IBA & $30.8 \pm 3.4$ & $3.5 \pm 0.4$ & $61.5 \pm 3.3$ & $40.8 \pm 4.5$ & $82 \pm 4.3$ & $49 \pm 4.4$ \\
\hline 1 & $12 \pm 0.1(n=13)$ & $7 \pm 0.4(n=15)$ & $21 \pm 0.5(n=13)$ & $18 \pm 0.9(\mathrm{n}=15)$ & $24 \pm 0.7(n=14)$ & $11 \pm 0.9(n=13)$ \\
\hline 2 & $24 \pm 1.6(n=17)$ & $9.8 \pm 0.4(n=20)$ & $59 \pm 2.0(\mathrm{n}=18)$ & $20 \pm 1.0(\mathrm{n}=18)$ & $49 \pm 1.4(n=18)$ & $17 \pm 0.8(\mathrm{n}=15)$ \\
\hline 3 & $1.1 \pm 0.1(\mathrm{n}=10)$ & $1.3 \pm 0.1(n=10)$ & $11 \pm 0.9(n=13)$ & $10 \pm 0.6(n=13)$ & $19 \pm 1.4(n=16)$ & $18 \pm 0.5(n=16)$ \\
\hline 4 & $19 \pm 1.0(\mathrm{n}=13)$ & $16 \pm 0.6(n=16)$ & $25 \pm 1.3(\mathrm{n}=16)$ & $13 \pm 0.6(n=16)$ & $43 \pm 1.2(n=16)$ & $17 \pm 0.4(\mathrm{n}=16)$ \\
\hline 5 & $10 \pm 0.2(\mathrm{n}=16)$ & $3 \pm 0.2(\mathrm{n}=15)$ & $38 \pm 1.0(\mathrm{n}=15)$ & $13 \pm 0.4(n=16)$ & $41 \pm 1.1(n=16)$ & $14 \pm 0.4(n=15)$ \\
\hline 6 & $35 \pm 1.3(\mathrm{n}=19)$ & $21 \pm 0.6(n=19)$ & $50 \pm 0.8(\mathrm{n}=18)$ & $27 \pm 0.6(n=18)$ & $41 \pm 1.5(n=18)$ & $16 \pm 0.8(n=18)$ \\
\hline
\end{tabular}


Table Continued

\begin{tabular}{|c|c|c|c|c|c|c|}
\hline \multirow{3}{*}{ Compound } & \multicolumn{6}{|c|}{ Concentration of compounds } \\
\hline & \multicolumn{2}{|l|}{100 ppm } & \multicolumn{2}{|l|}{10 ppm } & \multicolumn{2}{|l|}{$1 \mathrm{ppm}$} \\
\hline & Root & Shoot & Root & Shoot & Root & Shoot \\
\hline 7 & $3 \pm 0.1(\mathrm{n}=9)$ & $2 \pm 1.7(\mathrm{n}=10)$ & $\begin{array}{l}35 \pm 0.8 \\
(n=s 17)\end{array}$ & $15 \pm 0.4(n=16)$ & $38 \pm 0.9(n=18)$ & $12 \pm 0.3(\mathrm{n}=18)$ \\
\hline 8 & $56 \pm 2.0(n=18)$ & $22 \pm 0.8(\mathrm{n}=18)$ & $67 \pm 1.5(\mathrm{n}=17)$ & $20 \pm 0.9(n=18)$ & $50 \pm 1.7(n=19)$ & $15 \pm 0.8(n=19)$ \\
\hline 9 & $45 \pm 1.4(\mathrm{n}=18)$ & $13 \pm 0.6(n=18)$ & $61 \pm 1.7(n=17)$ & $25 \pm 0.9(n=18)$ & $57 \pm 2.1(\mathrm{n}=19)$ & $17 \pm 0.9(\mathrm{n}=19)$ \\
\hline 10 & NA & NA & $27 \pm 1.1(\mathrm{n}=18)$ & $18 \pm 0.5(n=18)$ & $25 \pm 1.0(\mathrm{n}=19)$ & $21 \pm 0.4(n=19)$ \\
\hline 11 & $13 \pm 1.1(\mathrm{n}=15)$ & $10 \pm 0.2(\mathrm{n}=15)$ & $19 \pm 0.5(n=14)$ & $12 \pm 0.3(n=14)$ & $15 \pm 1.7(n=16)$ & $11 \pm 0.4(\mathrm{n}=18)$ \\
\hline 12 & $27 \pm 1.3(\mathrm{n}=17)$ & $9 \pm 0.4(n=18)$ & $47 \pm 1.9(n=20)$ & $15 \pm 0.8(n=20)$ & $56 \pm 1.6(n=19)$ & $14 \pm 0.7(n=19)$ \\
\hline Control & \multicolumn{3}{|c|}{ Root length $48 \pm 1.3(\mathrm{n}=18)$} & \multicolumn{3}{|c|}{ Shoot length $26 \pm 1.1(n=18)$} \\
\hline
\end{tabular}<smiles>O=c1ccc2ccccc2o1</smiles><smiles>COc1ccc2ccc(=O)oc2c1</smiles><smiles>O=c1ccc2cc(O)ccc2o1</smiles>

2 3<smiles>Cc1cc(=O)oc2cc(O)ccc12</smiles>

4<smiles>Cc1ccc2ccc(=O)oc2c1</smiles>

5<smiles>Cc1cc(=O)oc2ccccc12</smiles><smiles>Cc1ccc2oc(=O)cc(C)c2c1</smiles>

8<smiles>Cc1cc(=O)oc2ccc(O)cc12</smiles><smiles>Cc1cc(=O)oc2cc(O)ccc12</smiles>

11<smiles>Cc1ccc2oc(=O)ccc2c1</smiles>

6<smiles>COc1ccc2c(C)cc(=O)oc2c1</smiles>

9<smiles>Cc1cc(O)c2c(C)cc(=O)oc2c1</smiles>

12
Figure I Chemical structure of coumarins Derivatives (I-I 2).

At 10 and $1 \mathrm{ppm}$, coumarins had no appreciable effects on seed germination. 7-Methoxycoumarin (2) was the most effective inhibitors of root growth at $100 \mathrm{ppm}$ compared with the control. However, root growth was induced by $20-40 \%$ at this concentration by $\mathbf{3}, \mathbf{6}$ and 7 . Similar profiles were observed at $10 \mathrm{ppm}$. 7-Hydroxycoumarin (4) inhibited root growths between $60-90 \%$ and compounds 3, 6, 7, 8, 12 had stimulatory effect on root growth compared with the control (Table 2) (Figure 3) Tartoura et al. ${ }^{12}$ showed that adventitious roots and root number increased with increasing concentration of coumarin and indole butyric acid, the maximum effect was seen at 1000 and $50 \mu \mathrm{M}$, respectively, relative to control. Neumann ${ }^{13}$ has shown that coumarin can stimulate the growth of plant organs/tissues contrary to our work. He worked on roots of sunflower that stimulated at $250 \mathrm{ppm}$ and its inhibitory effects were only observed at $1000 \mathrm{ppm}$. Goodwin $\&$ Taves ${ }^{14}$ have shown that coumarin is the most powerful root growth inhibitor but some of its derivatives were almost as active as coumarin itself, namely, 7, 8-dihydroxy coumarin, 7, 8-dihydroxy-4-methyl coumarin, 8-methyl coumarin and coumarin-3-carboxylic acid. However, 3-methyl substitution greatly diminished the inhibitory action on root growth.

\section{Sorghum}
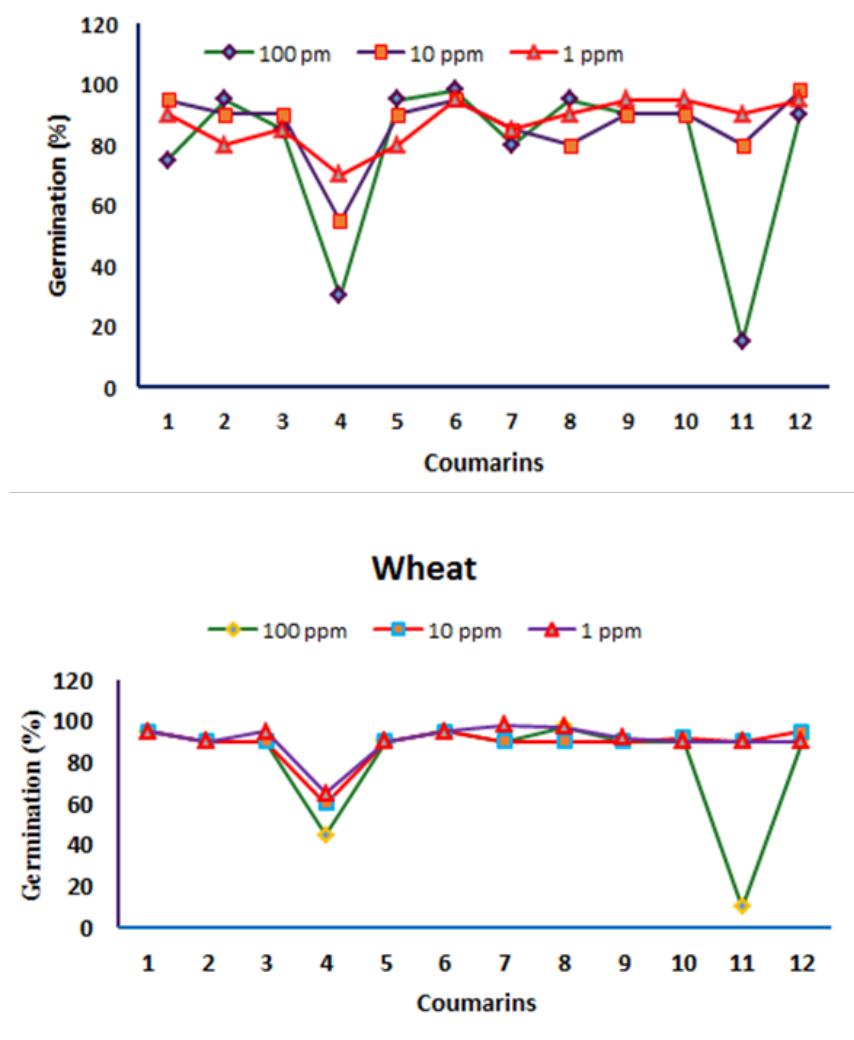

Figure 2 Effects of coumarins ( I - I 2) on sorghum and wheat seed germination at $25^{\circ} \mathrm{C}$. Results are mean of 3 independent experiments with 10 wheat and 20 sorghum seeds per experiment. Error is within $5 \%$ limit. Cont. is control.

\section{Effects on shoot length}

In wheat seeds, $\mathrm{ABA}$ showed reduced shoot length at 10 and 1 ppm but at $100 \mathrm{ppm}$ no increase shoot length was observed. While in sorghum seeds, reduced shoot length was observed at 100 and $10 \mathrm{ppm}$ but at $1 \mathrm{ppm}$ normal shoot length comparable to that of control was observed. On the other hand, in wheat, IBA at 10 and $1 \mathrm{ppm}$ exhibited normal shoot length but at $100 \mathrm{ppm}$ it reduced. In sorghum, IBA showed no particular effect on shoot length (Table 2) Shown in Figure 3. Shoot length $(\mathrm{mm})$ of developing seedlings was measured on $5^{\text {th }}$ day of germination. Compounds $\mathbf{4 , 5}$ and $\mathbf{1 0}$ at 100 ppm completely inhibited germination of wheat seeds and no shoot and root growth 
was observed (Figure 2). Reduced shoot growth was observed with 2, 7 and 11 whilst 7- 2, 3, 6, 7 exhibited shoot growth comparable to that of untreated or control. At $10 \mathrm{ppm}$, reduced shoot growth was observed by IBA and also by $\mathbf{3 , 5 , 6 , 8}$ and $\mathbf{1 2}$ demonstrated no increase in shoot length which was close to that of control group. At $1 \mathrm{ppm}$ concentration, reduced shoot length was observed by 1 and 5. These results indicate that compound $\mathbf{4}$ at 1 and $10 \mathrm{ppm} \mathrm{2,11}$ at $100 \mathrm{ppm}$ result in $60-85 \%$ reduction in shoot growth. Shoot length of sorghum seedlings on $5^{\text {th }}$ day of germination was completely inhibited by $\mathbf{5 , 2}$ and $\mathbf{1 1}$ at $100 \mathrm{ppm} . \mathbf{3 , 6}$ exhibited shoot length inducing activity and $10-20 \%$ induction in shoot length was observed. At $10 \mathrm{ppm} 8$ was the most effective inhibitor of shoot length whilst other compounds showed 20-40\% inhibition in shoot growth. Induction in shoot growth was observed in $\mathbf{2 ,} \mathbf{3}, \mathbf{6}$, and $\mathbf{1 2}$ at $10 \mathrm{ppm}$. At $1 \mathrm{ppm}, \mathbf{8}$ was again the most effective inhibitor of shoot growth (Figure 4).
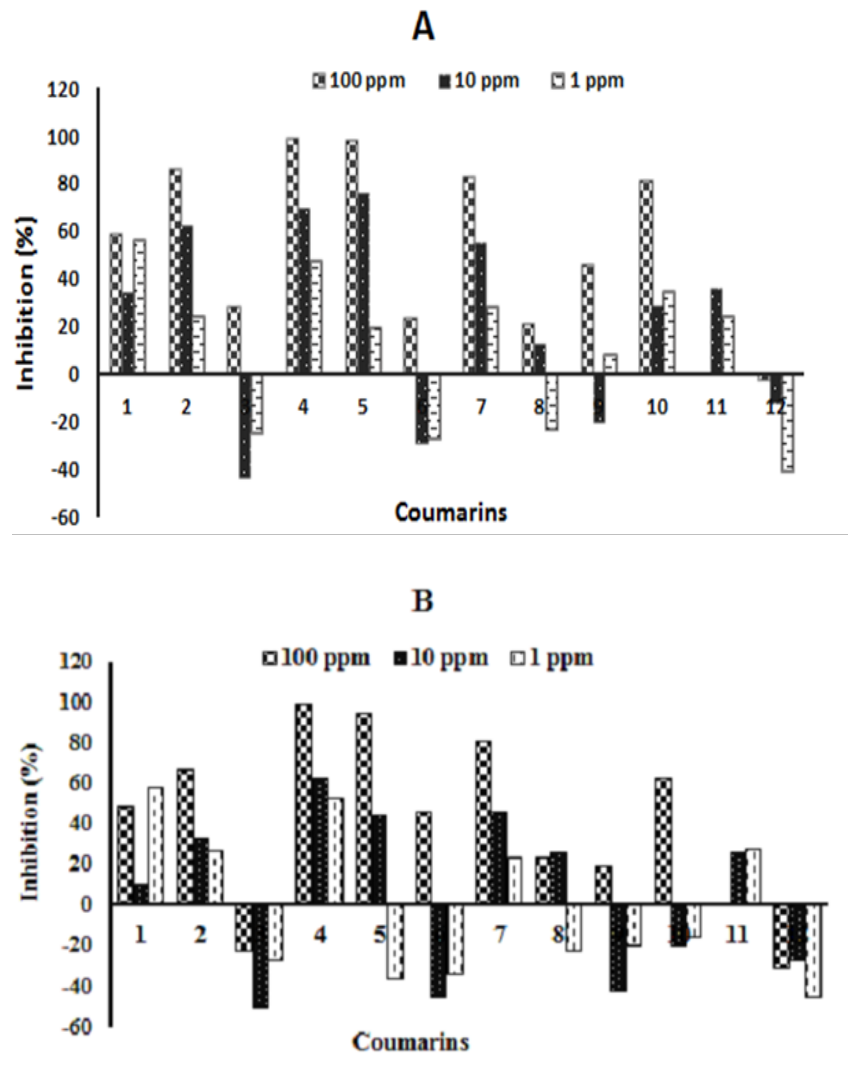

Figure 3 Effects of coumarins (I-I2) on percentage inhibition of root and shoot lengths of wheat seedlings. Results are mean of 3 independent experiments Error is within 5\% limit. Negative bar is growth stimulation instead of inhibition.

It was seen that only two compounds exerted germination inhibition effect but others did not have an appreciable effects on seed germination. In wheat, reduced shoot growth was observed with 2, 7 and 11 whilst other compounds 6, 7 and 12 exhibited normal shoot growth. Therefore, it can be said that in wheat seedlings at high concentration the effect of coumarin is inhibitory, at $10 \mathrm{ppm}$ its inhibitory effect on roots is more pronounced as compare to shoot, which at very low concentration of $1 \mathrm{ppm}$ except compound 2, 3, 4 and 12, others compounds are activators of growth. In this work it is concluded that in wheat all compound possessed inhibitory effect at $100 \mathrm{ppm}$ while at 10 and $1 \mathrm{ppm}$ most of coumarin are activators (Table 2) (Figure 3). In sorghum all compounds are shoot and root inhibitors at all concentration event at lowest concentration the effect is still inhibitory. It can also be noticed that at lower concentrations shoot growth is inhibited more prominently as compared to root (Table 3) (Figure 4).

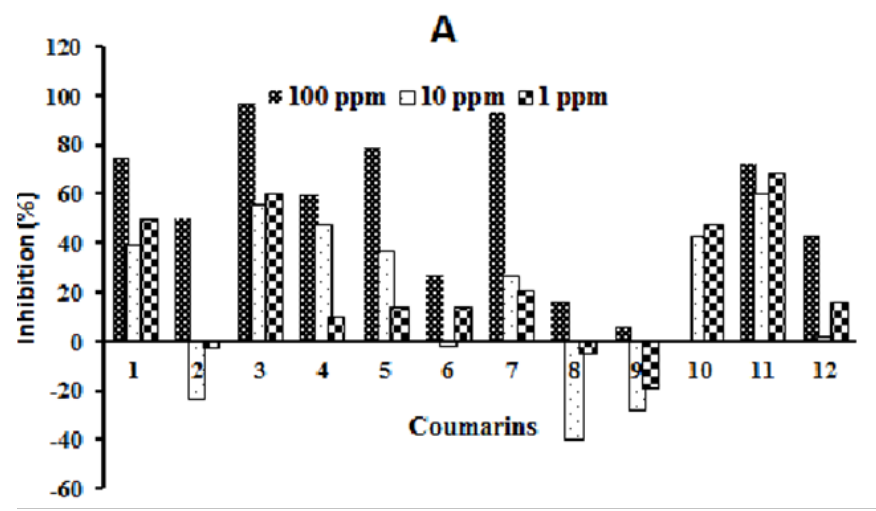

B

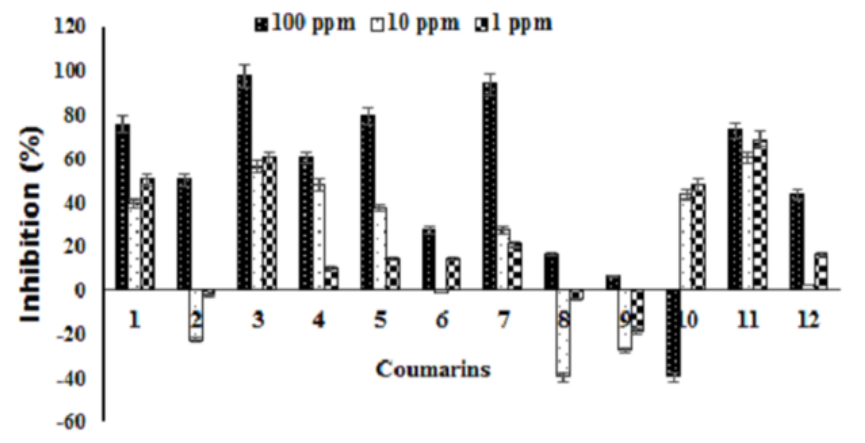

Figure 4 Effects of coumarins (I-I2) on percentage inhibition of root $(A)$ and shoot $(B)$ length of sorghum seedlings. Results are mean of 3 independent experiments Error is within $5 \%$ limit. Positive bars are growth inhibitors while negative are growth activators.

In literature, effects of coumarins have been found as growth inhibitory while according to our observations, coumarins are inhibitory at high concentration of $100 \mathrm{ppm}$ or up while these become growth activators at lower concentration of 10 or $1 \mathrm{ppm}$ especially in wheat while in sorghum its effect is inhibitor at all. According to Abenavoli et al. ${ }^{3}$ the inhibitory effects of coumarin used to be on the germination of durum wheat. The physiological and biochemical aspects thought to be critical for successful seed germination. At concentrations above $200 \mu \mathrm{M}$, coumarins inhibited seed germination that was dependent on. Inhibition occurred early during seed imbibitions which was rapid and irreversible. In our findings, nonpolar side exerted inhibiting effect more pronounced than coumarin itself; less polar had less or some time no effect and polar groups acted as activator instead of inhibitor. According to us greatest inhibition was observed at $100 \mathrm{ppm}$ root length of $1.0 \mathrm{~mm}, 2.0$ and again $1.0 \mathrm{~mm}$ were observed for $\mathbf{2 , 4}$ and $\mathbf{5}$ while at 1 ppm effect was not significant. Results show that only two compounds had inhibitory effects on seed germination and all other compounds had no effects on germination. 
In wheat reduced shoot growth was observed with 2, 7 and 11 whilst other compounds exhibited normal shoot growth.

\section{Conclusion}

The present work reveals the significance of coumarin derivatives as effective inhibitors of shoot and root growth in sorghum and wheat seedlings. Substituted coumarins with non-polar side chain exert more growth inhibition. Substituted coumarins mostly effective at high concentrations while some derivatives usually containing polar groups seems to exert no effect or have some accelerator at low concentration.

\section{Acknowledgement}

None.

\section{Conflict of interest}

None.

\section{References}

1. Karanov E. Effect of some indole and phenolic compounds on the ageing of aldewey. Verlag Chemie Weinheim. 1972;2:467-47.

2. Alexieva V, Karanov E, Nikolova R, et al. Plant growth regulating activity of some phosphorus derivatives of coumarin. Bulg J Plant Physiol. 1995;21(1): 45-51.

3. Napolitano HB, Silva M, Ellena J, et al. Aurapten, a coumarin with growth inhibition against Leishmania major promastigotes. Braz J Med Biol Res. 2004;37(12):1847-52.

4. Xu ZH, Qin GW, Xu RS. A new bicoumarin from stellera chamaejasme. J Asian Nat Prod Res. 2001;3(4):335-40.
5. Lee HK, Oh SR, Kwon OK, et al. Isolation of coumarins and ferulate from the roots of Angelica purpuraefolia and the antitumor activity of khellactone. Phytother Res. 2007;21(5):406-9.

6. Jiwajinda S, Santisopasri V, Ohigashi H. Coumarin-related compounds as plant growth inhibitors from two rutaceous plants in thailand. Biosci Biotechnol Biochem. 2000;64(2):420-3.

7. Goren R, Tomer E. Effect of seselin and coumarin on growth, indoleacetic aicd oxidase and peroxidase with special reference to cucumber radicles. Plant Physiol. 1971;47(2):312-316.

8. Chattha FA, Munawar MA, Ashraf M, et al. Antibacterial activity of coumarin and coumarin-3-acetic acids. Pak J Pharm Sci. 2015;28(3):819-823.

9. Noggle GR, Fritz GJ. Introduction to plant Physiology. Englewood Cliffs N J Prentice Hall. 1976;688.

10. Letham D. Naturally-occurring plant growth regulators other than the principal hormones of higher plants. In: D Letham, P Goodwin, $\mathrm{T}$ Higgins, editors, Vol 1, Phytohormones and Related Compounds - A Comprehensive Treatise. Elsevier /North-Holland;1978:349-417.

11. Abenavoli MR, Cacco G, Sorgonà $\mathrm{A}$, et al. The inhibitory effects of coumarin on the germination of durum wheat (Triticum turgidum ssp. durum, cv. Simeto) seeds. J Chem Ecol. 2006;32(2):489-506.

12. Tartoura K, da Rocha A, Youssef S. Synergistic interaction between Coumarin, 1,2-benzopyrone and indole-3-butyric acid in stimulating adventitious root formation in Vigna radiate (L) Wilczek cuttings: I. Endogenous free and conjugated IAA and basic isoperoxidases. Plant Growth Regulation. 2004;42(3):253-262

13. Neumann J. The auxin like action of coumarin. Science. 1959;129(3364):1675-6

14. Goodwin RH, Taves $\mathrm{C}$. The effect of coumarin derivatives on the growth of Avena roots. American Journal of Botany. 1950;37(3):224-231. 